\title{
Václavu Blažkovi k šedesátým narozeninám
}

Ti, kdo Václava Blažka znají, spojují si jej s Brnem, se kterým je spjat profesně již čtvrt století, v osobním životě ale s Příbramí, kde bydlí, nicméně ve skutečnosti se narodil v Sokolově (a to 23. dubna 1959) a první léta strávil v Lokti. Otec byl učitelem matematiky a fyziky a maminka byla malířkou porcelánu. Je zajímavé, že Václav zdědil talent po obou, jak dokazují Blažkovy zdařilé portréty slavných lingvistů, které zdobí ústavní chodby.

Do Př́ibrami se rodina přestěhovala později, vysokoškolské studium zahájil Blažek na pražské Karlově univerzitě a to, po otcově vzoru, na matematicko-fyzikální fakultě, ačkoliv již tehdy jeho široké zájmy jej vedly ke studiu lingvistiky, a proto si zapisoval patřičné kursy i na filosofické fakultě a navštěvoval různé soukromé přednášky kapacit, jako byli ugrofinista a teoretický strukturalista Vladimír Skalička, afrikanista a semitista Karel Petráček, íránista Petr Vavroušek a indologista a mongolista Jaroslav Vacek. Veselá léta studentská byla ovšem v zeleném stínu prezenční služby a Blažek po skončení studií musel odejít na vojnu. Pozoruhodnou shodou náhod nastoupil k tehdejšímu železničnímu vojsku v Pohořelicích a díky pochopení velících důstojníků mohl Blažek navštěvovat čas od času brněnské učence, zvláště indoevropeistu Adolfa Erharta, slavistu Arnošta Lamprechta a bohemistu Mirka Čejku (oba poslední byli zvláště zaujatí také „nostratickou teorií“, které se Blažek také začal věnovat). Takto se Blažek dostal do prvního kontaktu s brněnskou univerzitou, který později udržoval i jako učitel na učilišti v Př́ibrami. Při kariéře středoškolského učitele (se zajímavým koníčkem) by dost možná zůstalo, kdyby politické změny neumožnily Blažkovi nastoupit na postgraduální studia právě v Brně u Erharta, titul CSc. získal prací O zoologické terminologii $v$ indoevropských jazycích (savci) v roce 1993. Raná devadesátá léta také umožnila Blažkovi studovat v zahraničí, rok strávil v Kolíně nad Rýnem studiem jazykovědy u Hanse Jürgena Sasseho a afrikanistiky u Bernda Heineho.

Nakonec přišel čas definitivního přechodu: z Václava Blažka se stal odborný asistent na nově založeném Ústavu jazykovědy (dnes ... a baltistiky) na FF MU a Erhartův dědic. V roce 1998 zde byl habilitován (prací Numerals) v oboru indoevropeistika a v roce 2003 dosáhl ve stejném oboru profesury, stal se členem vědecké rady, publikoval stovky článků a několik monografií a vychoval již deset nových doktorů.

Vedle toho v Brně působil a působí v různé míře i v Etymologickém oddělení Ústavu pro jazyk český, zejména významný je jeho podíl na vydávání tamního Etymologického slovníku jazyka staroslověnského, a to jak v roli autora, tak také konzultanta. 
Blažkovy vědecké zájmy jsou široké, ale přece jen můžeme jmenovat hlavní pole: etymologii, nejen indoevropskou, ale v zásadě jakoukoliv (v sérii studií pokryl rozsáhlé ćásti slovníku jazyka bedža), onomastiku ( $\mathrm{k}$ té se dostal více až po roce 200o), otázku př́buznosti jazykových rodin (zvláště makrorodiny nostratické a rodiny altajské, prvnímu tématu se věnuje vlastně průběžně, druhému v posledních letech), jeho matematické pozadí se projevuje v studiích ke glottochronologii a lexikostatistice, v posledních letech píše i drobnější studie $\mathrm{k}$ dějinám lingvistiky.

Souborná bibliografie knih, studií a článků (bez recenzí a bibliografií) k roku 2018 činí 417 položek (viz Dufková in print), nicméně od té doby narostla o několik dalších položek, které jsou přiloženy $\mathrm{k}$ tomuto medailonu jako dodatek.

Blažek je nejen úspěšný jako vědec a pedagog, ale je oblíbený jako člověk. Jeho kolegové z fakulty i odjinud si váží jeho ochoty pomáhat, která přesahuje běžné služební povinnosti, protože plyne z vrozené laskavosti.

Blažkovi k šedesátým narozeninám jeho kolegové a přátelé připravili festschrift (Bichlmeier - Šefč́́k - Sukač in print), který snad již brzy vyjde v hamburském nakladatelství Baar, nicméně je dobré jej připomenout takto i na stránkách Linguisticy Brunensie, ve které je nejen členem redakčního kolektivu, ale hlavně dlouholetým a plodným přispěvatelem již od dob, kdy se ještě jmenovala Sborník prací filosofické fakulty brněnské university, řada A. A za kolektiv Linguisticy ještě jednou vše nejlepší a další plodná a činorodá léta!

\section{LITERATURA}

DUFKovÁ, KRISTÝNA. In print. A Selected Bibliography of Václav Blažek. In: BichLMEIER, Harald - ŠEFČ́́k, Ondřej - SUKAČ, Roman, eds. Etymologus. Festschrift for Václav Blažek. Hamburg: Baar, 13-40.

BichLMEIER, Harald - ŠEFČír, Ondřej - SUKAČ, Roman, eds. In print. Etymologus. Festschrift for Václav Blažek. Hamburg: Baar.

\section{Ondřej Šefčík}

Department of Linguistics and Baltic Languages

Faculty of Arts, Masaryk University

A. Nováka 1, 60200 Brno

Czech Republic

sefcik@phil.muni.cz 